\title{
Life imprisonment: a relic of the past or dira recessitas
}

\author{
Maksim Anatolievich Tuliglovich ${ }^{1 *}$, Aleksander Vitalievich Shvets ${ }^{2}$, Nodar Shotaevich \\ Kozaev $^{3}$, Boris Vasilyevich Epifanov ${ }^{4}$, and Suhrob Saidakhmad Narzullozoda ${ }^{5}$ \\ ${ }^{1}$ The Far Eastern branch of the Federal State Budget-Funded Educational Institution of Higher \\ Education "The Russian State University of Justice", Department of Criminal Law, Khabarovsk, \\ Russia \\ ${ }^{2}$ Amur State University, Department of Civil Law, Blagoveshchensk, Russia \\ ${ }^{3}$ Krasnodar University of the Ministry of Internal Affairs of Russia, Stavropol, Russia \\ ${ }^{4}$ Saint Petersburg University of the Ministry of Internal Affairs of Russia, Saint Petersburg, Russia \\ ${ }^{5}$ The Academy of the Ministry of Internal Affairs of the Republic of Tajikistan, Dushanbe, Tajikistan
}

\begin{abstract}
The existence of life imprisonment in the criminal legislation of Russia is assessed ambiguously both by representatives of Russian science and by foreign analysts. This problem is many-sided and ambiguous in its content. Its solution depends on a large number of variables, sometimes independent of the subject of analysis. These include trends in criminal policy, the state of crime in the state, and the related "punitive claims" of the population. The balance of Domestic and International Interests in ensuring Human Rights is the key idea in analyzing life imprisonment from the perspective of historical viability or reality. The purpose of the research was to clarify the place and role of life imprisonment in the current system of criminal punishment based on the analysis of doctrinal approaches, the practice of the Constitutional Court of the Russian Federation, the European Court of Human Rights, and statistical data. The work is based on the use of such general scientific methods of research as dialectical, statistical, comparative-legal and hermeneutic. The above methods are used in interaction to obtain a synergistic effect. In the course of the study, the "deterrent" mechanism of the most severe punishment in the criminal system was found to be sufficient. It is determined that life imprisonment is a necessary measure to ensure social justice, albeit cruel, but appropriate in today's society.
\end{abstract}

Keywords: life imprisonment, punishment, prevention of crimes, penal sanctions

\section{Introduction}

Life imprisonment, as the most severe type of punishment, has given rise and continues to give rise to controversial opinions and judgments not only by society, but also by experts who are deeply immersed in the study of crime prevention problems in Russia and abroad [1].

\footnotetext{
*Corresponding author: tu-m-an@yandex.ru
} 
Theoretical justification and serious scientific development of punishment in the form of life imprisonment in modern Russia began relatively recently, in view of the insignificant period of its application. Discussions of proponents and opponents of its application revolve around a fairly wide range of issues. The consistent resolution of which will allow a new assessment of the necessity and appropriateness of this type of punishment in the system of measures of criminal justice response to crime in Russia and to answer the question: whether this type of punishment is a relic of the past or a brutal necessity in today's environment. The problem is that the answer to most of them, such as predicting the effectiveness of its preventive impact and correctional effect [2] is possible only after a long time, when there is enough information for a comprehensive analysis of the recidivism rate of life-time prisoners. In particular, according to the results of the study of the institution of parole from serving the sentence. Given the absence of such practice in Russia, it is possible to do so only by analyzing foreign sources that examine the recidivism rate of persons released on parole from life imprisonment [3,4].

\section{Results}

Analysis of statistical data shows that the number of persons sentenced to life imprisonment annually in the Russian Federation fluctuates on average from 64 to 70 . The majority of those sentenced to life imprisonment are those who have committed qualified murders (part 2, article 105 of the Russian Criminal Code) (see diagram below) 1). In contrast to certain foreign countries, such as Ireland, where the dramatic increase in the number of life sentences is influenced by the mandatory nature of life imprisonment for murder [5], the availability of alternative sanctions in Russia provides a sufficient level of individualization of punishment.

We can observe the absence of both positive and negative dynamics, except for sharp jumps in 2003 (93 people), in 2004 (89 people), and in 2016 (94 people). It can be assumed that the increase in the number of convicts during these periods is associated in particular with changes in criminal legislation aimed at increasing the number of crimes punishable by life imprisonment.

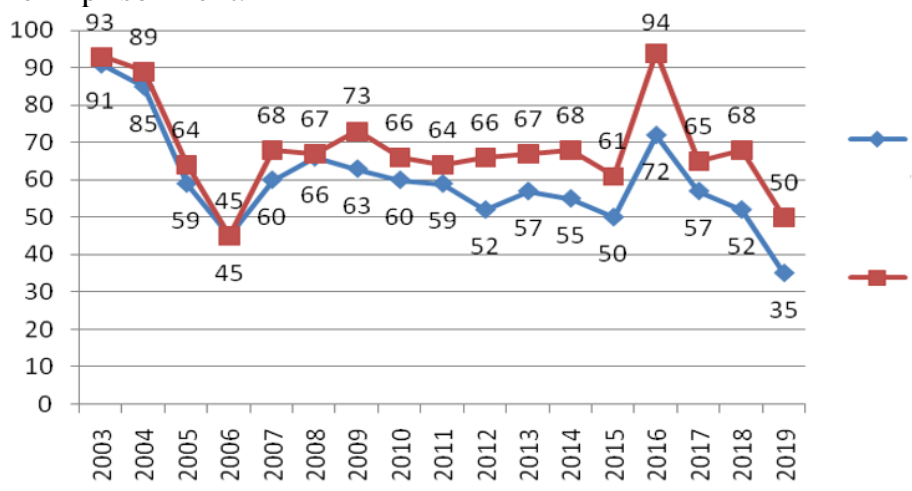

Convicted to life imprisonment for qualified murders (Part 2, Article 105 of the Criminal Code of the RF)

Total convicted to life imprisonment

Fig. 1. Number of persons sentenced to life imprisonment for qualified murders (Part 2, Article 105 of the Criminal Code of the Russian Federation).

Given the fairly stable annual rates of persons sentenced to life imprisonment, one can conclude that in the minds of philistines (those with conformist behavior), as well as those who are prone to marginal behavior, fear of criminal punishment is the main deterrent to illegal behavior. And the harsher the punishment, the more unavoidable it is, the greater the prevention effect among this population. Therefore, the "deterrent" potential of life imprisonment, as the most severe type in the current system of punishment, within the framework of general and special prevention seems to be the most significant (weighty). 
Given the consistently high rates of registered crime in Russia, one can assume that life imprisonment is a necessary measure of social justice, albeit a cruel one, in modern society.

\section{Discussion}

World practice knows two global varieties of life imprisonment such as absolute and relative. The former is condemned and recognized by international justice as inhumane [6], and contrary to Article 3 of the Convention for the Protection of Human Rights and Fundamental Freedoms [7]. The case of Vinter and Others v. the United Kingdom (complaints nos. $66069 / 09,130 / 10$ and 3896/10). Life imprisonment has appealed to the applicant without the right to early release. In this case, there was a violation of the requirements of Article 3 of the Convention for the Protection of Human Rights and Fundamental Freedoms [8].

For example, Esther Gumboh writes, "the lack of a clear legislative definition of life imprisonment and the inadequate system of release the use of life imprisonment in Malawi is incompatible with the Bill of Rights and international penal standards" [9]. And although life imprisonment in the criminal legislation of Russia has a relative nature, since it is possible to be released on parole from serving the sentence (Part 5, Article 79 of the Criminal Code), the legal uncertainty of certain provisions of the criminal law, the lack of legal mechanisms of conditional release, "de facto" makes this punishment an absolute.

Proponents of humanization and, consequently, opponents of the introduction of life imprisonment in the system of criminal punishment, have different opinions on the expediency of such changes. Karpets believed that this punishment is not justified either humanely or legally [10]. The arguments presented by the author clearly demonstrate the ethical (moral) side of the problem in question. However, in the literature, there is also an indication of the other side of morality. "How fair is it to continue the life of a condemned man at the expense of the relatives of the murdered man? Isn't it immoral to keep murderers alive for life at the taxpayers' expense?" [11]. Any idea can be taken to the point of absurdity; the main thing is not to allow violations of fundamental human rights. As Zagraevsky rightly noted: "State expenditures for the maintenance of life-sentenced prisoners are in fact expenditures for the moral formation of society" [12].

Voices that the concept of life imprisonment contradicts the very idea of human rights protection are heard among foreign authors [13] and in the European Court of Human Rights. In his dissenting opinion, ECHR judge Paulo Pinto de Albuquerque presented his views on the place and role of life imprisonment in Russian national legislation, pointing to its ineffectiveness [6]. It is not excluded that similar opinions are expressed in our country.

However, it is difficult to say to what extent the goal of social reintegration will be achievable for all prisoners as a result of the abolition of life imprisonment. One should not forget about the existence in Russian criminal law of the possibility of imposing extra-long sentences of 25 and 30 years, which, by and large, is comparable to life imprisonment. Strictly speaking, the individual arguments made by Paulo Pinto de Albuquerque, in particular the impact of the abolition of life imprisonment on reducing general or violent crime in Portugal, require critical reflection. Since the determinants of crime, as a complex social phenomenon, depend on many factors, and to correlate them exclusively with the presence of life imprisonment in the penal system is not entirely justified. It should be noted that life imprisonment is stipulated by most European states. For example, Smit and Morrison, exploring the paradoxes of Scottish life imprisonment, point out that more people serve life sentences in Scotland than in any other country in Europe [14].

Malko urged to treat the use of life imprisonment as an alternative to the death penalty with caution, taking into account the conditions of detention in Russian correctional institutions [15]. Realizing the possibility of moving to the category of "eternal convicts", many convicts applied for capital punishment, pointing to the excessive hardship and 
deprivation of life imprisonment $[16,17]$. However, this opinion is not shared by the highest court, and the replacement of the death penalty by life imprisonment has repeatedly been recognized by the Constitutional Court of the Russian Federation as a measure that does not worsen the situation of the convicted person [18].

Another argument of opponents of long and life terms of imprisonment is their inexpediency and ineffectiveness from the standpoint of psychology and sociology [19]. These data are also confirmed by foreign researchers [20].

Although not in such emotional tones, however, using no less reasoned arguments, proponents of the introduction of life imprisonment assess its appropriateness and effectiveness in different ways [21,22]. The ideas of introducing life imprisonment into the system of criminal punishment find support not only in Russia, mainly as an effective measure to isolate especially dangerous criminals [3]. However, most of the arguments in favor of life imprisonment are heard when discussing the adequate replacement of the death penalty [23].

\section{Conclusion}

The balance between domestic and international interests in securing human rights is the key idea of applying life imprisonment from the perspective of historical expediency or reality. Finding this balance shows the level of development of not only the state, but also social mechanisms.

Thus, it can be stated that the problem of justification of the very existence of life imprisonment is multifaceted and ambiguous. The answer depends on too many variables, sometimes independent of the subject of analysis. Here it is necessary to take into account both the level of crime and the level of morality and culture of the members of society themselves, their tolerance for those who commit especially serious crimes, and the level of development of the penal system, and much more. In any case, a more detailed dive into the essence of life imprisonment, especially to distinguish it from other types of punishment, will help to better understand this issue.

\section{References}

1. K. Filipcic, Crimen. 10(3), 225-238 (2019). https://doi.org/10.5937/crimen1903225F

2. M.A. Tuliglovich, Jurid. Sci. and Law Enfor. Pract. 54(4), 34-43 (2020)

3. J. Anderson, Curr. Iss. in Crim. Just. 31, 1-14 (2019). https://doi.org/10.1080/10345329.2019.1605870

4. M. Jarding, Contemp. Just. Rev. 21, 1-2 (2017). https://doi.org/10.1080/10282580.2017.1377484

5. D. Griffin, The Rise of Life Imprisonment (Springer, 2018). https://doi.org/10.1007/978-3-319-72667-0_2

6. ECtHR judgment of January 24, 2017. The case of Khamtokhu and Aksenchik $v$. Russian Federation. (complaints № 60367/08 and 961/11), in Bul. of the Europ. Court of Human Rights 3, 151 (2017)

7. ECtHR judgment of 09 July 2013. Accessed on: March 24, 2021. [Online]. Available: http://hudoc.echr.coe.int/eng?i=001-122183

8. Convention for the Protection of Human Rights and Fundamental Freedoms, in Precedents of the European Court of Human Rights, 42(6) (2017)

9. E. Gumboh, J. of Afric. Law 61, 443-466 (2017). 
https://doi.org/10.1017/S0021855317000250

10. I. I. Karpets. Polza ili zlo [Benefit or Evil], in S.G. Kelina (ed.), Smertnaya kazn: za i protiv [The Death Penalty: For and Against] (Yuridicheskaya lituratura, Moscow, 1989)

11. E.L. Kiryukhina, Ugolovno-pravovye i ugolovno-ispolnitelnye aspekty primeneniya nakazaniya $v$ vide pozhiznennogo lisheniya svobody [Criminal-legal and criminalexecutive aspects of the application of punishment in the form of life imprisonment], $\mathrm{PhD}$ thesis (Moscow, 2008)

12. S.V. Zagrayevsky, Smertnaya kazn ili pozhiznennoe lishenie svobody? [Death penalty or life imprisonment?]. Accessed on: March 24, 2021. [Online]. Available: http://zagraevsky.com/death.htm

13. Z.S. Dirk, Punishm. \& Soc. 3, 299-306 (2001). https://doi.org/10.1177/14624740122228348

14. Z.S. Dirk \& K. Morrison, Europ. J. of Crime, Criminal Law and Criminal Just. 28, 76102 (2020). https://doi.org/10.1163/15718174-02801004

15. A.V. Malko, Pravozovedenie, 1, 115, (1998)

16. N.D. Uzlov, Suicidology, 18(1), 45 (2015)

17. V.N. Andreeva, Smertnaya kazn i pozhiznennoe lishenie svobody kak ee alternativa [Death penalty and life imprisonment as its alternative], PhD thesis (Krasnodar, 2000)

18. Opredeleniya Konstitutsionnogo Suda Rossiiskoi Federatsii ot 11 yanvarya 2002 g. № 60-O i 61-O; ot 19 fevralya 2003 g. № 77-O; ot 21 dekabrya 2004 g. № 466-O; ot 21 dekabrya 2006 g. № 567-O; ot 15 yanvarya 2009 g. № 276-O-O; № 280-O-O, № 281O-O; № 282-O-O; № 283-O-O; № 284-O-O [Rulings of the Constitutional Court of the Russian Federation of 11 January 2002, No. 60-O and 61-O; 19 February 2003, No. 77-O; 21 December 2004, No. 466-O; 21 December 2006, No. 567-O; 15 January 2009, No. 276-O-O; No. 280-O, No. 281-O; No. 282-O; No. 283-O; No. 284-O]. Accessed on: March 24, 2021. [Online]. Available: http://ksrf.ru/ru/Decision/Statisticses/Pages/Definition.aspx

19. V.U. Yalunin, Rossiiskii opyt ispolneniya nakazaniya $v$ vide pozhiznennogo lisheniya svobody [Russian experience of execution of punishment in the form of life imprisonment], in Proc. 15th session of the Council of Europe Steering Group on the reform of the Russian penal system, 29-30 April, Lubeck (2003)

20. B. Gumilar, G. Gunarto, A. Khisni, J. Daulat, Hukum, 2, 499 (2020). https://doi.org/10.30659/jdh.v2i4.8348

21. E.P. Ishchenko, Penitentiary Sci. 3, 28 (2008)

22. V.N. Kudryavtsev, Strategii borby s prestupnostyu [Strategies to Combat Crime] (Jurist, Moscow, 2003)

23. Malikov B.Z. Teoreticheskie problemy sushchnosti i soderzhaniya lisheniya svobody i ikh vyrazhenie v ugolovnom i ugolovno-ispolnitelnom zakonodatelstve Rossii [Theoretical problems of the essence and content of imprisonment and their expression in the criminal and criminal-executive legislation of Russia], Doctoral thesis (Ryazan, 2004) 